\title{
Assessment of Trace Metals Leaching During Rainfall Events from Building Rooftops with Different Types of Coverage - Case Study
}

\author{
Nicole Nawrot ${ }^{1 *}$, Ewa Wojciechowska ${ }^{1}$ \\ 1 Gdańsk University of Technology, Faculty of Civil and Environmental Engineering, Department of Sanitary \\ Engineering, ul. Narutowicza 11/12, 80-233 Gdańsk, Poland \\ * Corresponding author's e-mail: nicnawro@pg.edu.pl
}

\begin{abstract}
Runoff water is an important medium transporting various types of pollution originating from the atmosphere and washed out from roofing materials. The study presents a quality assessment of runoff from different roofs in the context of trace metal concentrations. The analysed rooftops were covered with copper, tar paper and ceramic tile. The quality of the rain water collected at the same time satisfies the demands of the first grade of cleanliness according to (Journal of Laws, 2016 item1187). The highest content of copper was leached from the copper roof, containing $10.23 \mathrm{mg} \cdot \mathrm{dm}^{-3}$. In the case of zinc, the highest concentration of $15.52 \mathrm{mg} \cdot \mathrm{dm}^{-3}$ was present in the runoff from the roof covered with thermally bonded tar paper. The amount of trace metals in the ceramic roof runoff was the lowest and only for zinc slightly exceeded $1.47 \mathrm{mg} \cdot \mathrm{dm}^{-3}$ - the value determined for II class of purity. In the paper, the different levels of heavy metals leaching from different roofing materials have been confirmed.
\end{abstract}

Keywords: trace metals, roof materials, precipitation, roof runoff

\section{INTRODUCTION}

The high-density urban areas are characterized by the presence of significant areas (in $\mathrm{km}^{2}$ ) of impervious surfaces, e.g. routes of car communication, pavements and roofs of the buildings [Chang et al., 2004]. They cover approximately $80 \%$ of the total area [Kaye et al., 2006]. The roofs of buildings are made of various materials and the majority of runoff from their surface (with the exception of green roofs or roofs made of natural materials) is a source of pollution in the environment [Polkowska and Namieśnik, 2008]. Typical materials used for roofing are ceramic tiles, metal sheets (steel, aluminum, zinc-titanium, copper), thermally bonded tar paper, bituminous shingle. In some buildings from the 1960s and 1970s, the roof coverings made of eternit (containing asbestos fibers) may also occur. However, in Poland,in accordance with the Resolution no. 122/2009 of the Council of Ministers from July 14 ${ }^{\text {th }}, 2009$ - this kind of roofing material must be removed and disposed of until the end of 2032. Material durability and aesthetics are important during the designing stage of buildings and selection of the finishing materials. Copper is a versatile material, valued, very durable and used in construction for centuries. Nevertheless, it is a heavy metal, which can be a threat for the aquatic ecosystem in water receivers if the concentration is too high [Snaddon and Treblay, 2011]. The cover made of tar paper is a kind of preliminary roofing. It is a relatively cheap solution, especially recommended when the final roofing coverage is delayed until the next season. The roofing made from ceramic tiles is also a frequently used solution due to the durability of this material - which is estimated to be 100 years.

Rainwater becomes contaminated already during precipitation [Ociepa et al., 2010]. The analysis of rainwater samples taken during the first stage of precipitation gives indirect information on the state of air quality [Tsakovski et al., 2010]. Many contaminants are deposited on roofs of buildings during long dry periods so-called dry deposition. The analysis of runoff 
from roofs, in addition to providing information on the condition of the atmospheric air, also allows for the analysis of contaminants leached from the materials constituting the roof covering. The runoff from roofs may constitute an undesirable source of point pollution [Chang et al., 2004] with a composition depending on the composition of rainwater, roof age [Wallinder et al., 2001], type of coverage, inclination, location and meteorological factors [Evans et al., 2006]. The analysis carried out by Tsakovski et al. [2010] showed the content of zinc within runoff from the roof covered with galvanized sheet was on an average level of $0.066 \mathrm{mg} \cdot \mathrm{dm}^{-3}$, while in the case of the roof covered with ceramic tiles, it ranged from 0.038 to $0.112 \mathrm{mg} \cdot \mathrm{dm}^{-3}$. Polkowska and Namieśnik [2008] reported the zinc concentration at the level of $4.900 \mathrm{mg} \cdot \mathrm{dm}^{-3}$ in the runoff from the roof covered with asbestos cement sheets, while the highest lead content -0.102 $\mathrm{mg} \cdot \mathrm{dm}^{-3}$ - was recorded for runoff from a flat roof covered with tar paper. The highest content of cadmium occurred in the runoff from ceramic tiles $-0.037 \mathrm{mg} \cdot \mathrm{dm}^{-3}$, whereas copper was detected only in the samples of water coming from the roofs covered with tar paper and ceramic tiles [Polkowska and Namieśnik, 2008]. The highest concentrations of pollutants in runoff from various types of surfaces are detected in the first stage of run-off (so-called first flush). The research conducted for various roofing materials suggests that each type of coverage requires different quantity and duration of the first rainwater runoff, until the quality of the rainwater flowing from the roof is improved [Kim et al., 2005]. The rainwater runoff from the roofs of the buildings and a large part of surface runoff in the Gdańsk Oliwa district is discharged to the rainwater drainage system, and then by rainwater outlets to the nearby receiver - Oliwa Stream (Jelitkowo Stream), where 13 retention tanks are located. Oliwa Stream flows out directly to the Gulf of Gdańsk in Jelitkowo district, where the beach for inhabitants and tourists is organized in the summer.

\section{MATERIALS AND METHODS}

Three buildings with the different types of roofing located in Gdańsk Oliwa district were selected - copper roof $(\mathrm{M})$ - inclination angle $60^{\circ}$, roof covered with thermally bonded tar paper $(\mathrm{P})$ - inclination angle $5^{\circ}$ and ceramic roof tile (C) $-45^{\circ}$ angle of inclination. The samples were collected during the rain events, which took place in the summer of 2017. The following heavy metals were selected for analysis: zinc, copper, aluminum, lead and cadmium. The content of trace metals in rainwater samples (taken during the rain episodes into a glass bottle with a wide spout) was also analyzed.

The amount of rainfall and weather conditions for the selected rain events are shown in Table 1. The amount of rainfall was obtained for the Oliwa IBW PAN station - the data was provided by the municipal company Gdańskie Wody in Gdańsk [http://pomiary.gdmel.pl/].

The buildings are located at a distance of 150 $\mathrm{m}$ in a straight line from each other. The location of buildings is shown in Figure 1. For comparison purposes, a rainwater sample (WD) was also taken while collecting the first sample from the roof (nearby the Oliwa Cathedral). The samples were collected during three precipitation episodes (each sample in triplicate) in the period from June to August 2017, by collecting the outflow from the roof at the outlet from the external vertical gutter (outlet directly to the surface).

On the basis of the knowledge of roof dimensions, the intensity of rainwater runoff from roofs $\mathrm{Q}_{\mathrm{D}}$ was determined in accordance with the following formula (1):

$$
\mathrm{Q}_{\mathrm{D}}=\mathrm{r} \cdot \mathrm{C} \cdot \mathrm{A}\left[\mathrm{dm}^{3} \cdot \mathrm{s}^{-1}\right]
$$

where: $r$ - intensity of atmospheric precipitation, $\left[\mathrm{dm}^{3} \cdot \mathrm{s}^{-1} \cdot \mathrm{m}^{-2}\right]\left(\mathrm{r}=0.0173 \mathrm{dm}^{3} \cdot \mathrm{s}^{-1} \cdot \mathrm{m}^{-2}\right.$, for the duration of precipitation $\mathrm{T}=15 \mathrm{~min}$, probability $\mathrm{p}=20 \%$ and the frequency of rain $\mathrm{c}=5$, according to the formula Bogdanowicz and Stachy [Kotowski A., et al., 2010]

Table 1. Weather conditions and precipitation for IBW PAN station

\begin{tabular}{|l|c|c|c|c|}
\hline \multirow{2}{*}{$\begin{array}{c}\text { Precipitation } \\
\text { event }\end{array}$} & Temperature $\left[{ }^{\circ} \mathrm{C}\right]$ & Cloud cover [\%] & \multicolumn{2}{|c|}{ Total rainfall height [mm] } \\
\cline { 4 - 5 } & & $40-60$ & $\begin{array}{c}\text { In the day of a rainfall } \\
\text { episode }\end{array}$ & $\begin{array}{c}\text { In the day before the rainfall } \\
\text { episode }\end{array}$ \\
\hline 1 - June & 19 & $60-80$ & 6.6 & 0.0 \\
\hline 2 - July & 19 & $60-80$ & 7.8 & 0.1 \\
\hline 3 - August & 18 & 10.8 & 0.0 \\
\hline
\end{tabular}




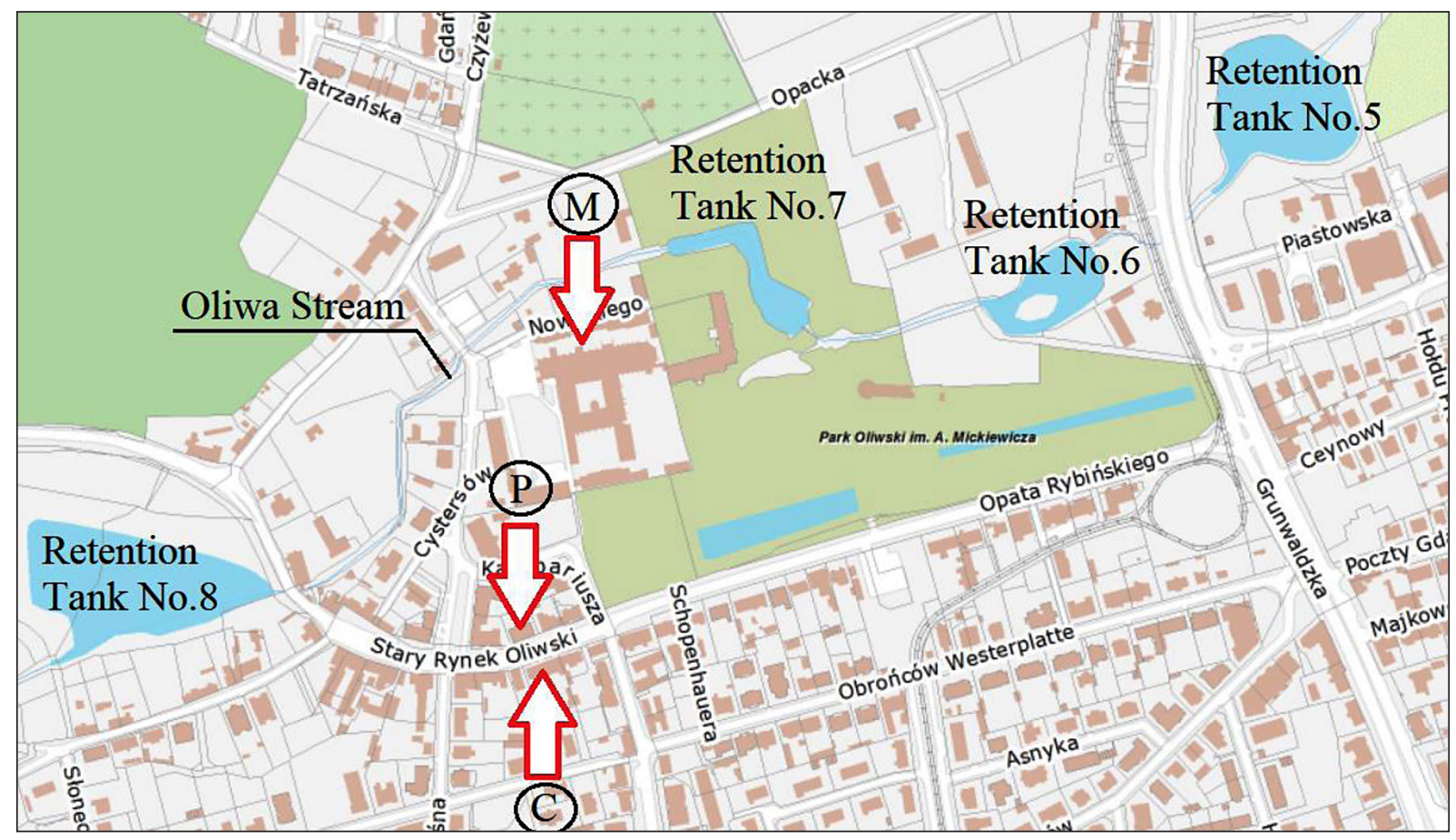

Figure 1. Location of sampling points from roofs:

$\mathrm{M}$ - copper roof, $\mathrm{P}$ - thermally bonded tar paper, $\mathrm{C}$ - ceramic roof

$C$ - runoff coefficient, [-], C $=1.0$ (according to PN-EN 12056-3: 2002)

$A$ - effective roof area, $\left[\mathrm{m}^{2}\right]$

In the case of simplified conditions (when no correction is made due to the influence of wind), the effective roof surface is determined in accordance with the formula (2):

$$
\mathrm{A}=\mathrm{L}_{\mathrm{R}} \cdot \mathrm{B}_{\mathrm{R}}\left[\mathrm{m}^{2}\right]
$$

where: $L_{R}-$ length of the roof from which water is drained, [m]

$B_{R}-$ width of the roof from the gutter to its top, [m]

For the analyzed buildings the flow rate of runoff from roofs $\mathrm{Q}_{\mathrm{D}}$ was, respectively:

a) Oliwa Cathedral $(\mathrm{M}): \mathrm{Q}_{\mathrm{D}}=29.4 \mathrm{dm}^{3} \cdot \mathrm{s}^{-1}$

b) Building at Stary Rynek street $19(\mathrm{P})$ :

$\mathrm{Q}_{\mathrm{D}}=7.3 \mathrm{dm}^{3} \cdot \mathrm{s}^{-1}$

c) Building at Stary Rynek street 3 (C):

$\mathrm{Q}_{\mathrm{D}}=3.5 \mathrm{dm}^{3} \cdot \mathrm{s}^{-1}$

The samples were collected to half-liter, glass bottles in the initial phase of precipitation (during the first 15 minutes of rainfall), then transported to the laboratory (within of 4 hours from collecting) and filtered using 0.45 pore diameter syringe filters. Afterwards, $10 \mathrm{ml}$ of the test sample was poured into a $15 \mathrm{ml}$ test tube and acidified with nitric acid. In brief, 3 test tubes filled with runoff from the roof were prepared from each measuring point, i.e. from each half-liter bottle, which ensured proper control of the results during the measurement using spectroscopy. Subsequently, the trace metals concentrations $(\mathrm{Zn}, \mathrm{Cu}, \mathrm{Pb}, \mathrm{Cd}$ and $\mathrm{Al}$ ) were measured by inductively coupled plasma-mass spectroscopy (ICP-MS). The ICPMS spectrometer is equipped with a standard ICP quartz burner, nebulizer, nickel cones. Samples and standards are given using a peristaltic pump. The spectrometer is optimized daily using a solution of $10 \mu \mathrm{g} \cdot \mathrm{dm}^{-3}(\mathrm{Mg}, \mathrm{Cu}, \mathrm{Rh}, \mathrm{Cd}, \mathrm{In}, \mathrm{Ba}$, $\mathrm{Ce}, \mathrm{Pb}, \mathrm{U}$ ) in $1 \% \mathrm{HNO}_{3}$. The samples were analyzed in a liquid form by means of a dosing system consisting of a sprayer and a mist chamber. ELAN 9000 contains a quadrupole mass distribution system in the range of 1 to 269 atomic mass units (amu). An RF generator with a frequency of $40 \mathrm{MHz}$ is used in the power range from 500 to $1600 \mathrm{~W}$. The ETP two-stage detector enables operation in pulse and analog signal measurement modes (measuring range from 1 to 109 counts/s). It includes a vacuum maintenance system comprising a vacuum and turbulent pump. The results are produced in $\mu \mathrm{g} \cdot \mathrm{dm}^{-3}$.

The assessment of the quality of collected water samples was carried out using the classification given in the Regulation of the Environmental 
Minister of July 21, 2016 (REM) on the method of classification of uniform surface water bodies. The classification included in REM was chosen due to the fact of a specific rainwater drainage system in Gdańsk, where the Oliwa Stream is a receiver for the rainwater drainage system; thus, the runoff from roofs can have a significant impact on the temporary content of trace metals in water of Oliwa Stream. According to Annexes No. 6 and No. 9 to the Regulation [Journal of Laws, 2016 item 1187] limit values for the metals tested are at the level shown in Table 2. Class I corresponds to the waters with very good chemical status, class II - waters with good chemical status, while the waters of III, IV, V class are considered for average to bad chemical status.

\section{RESULTS AND DISCUSSION}

The statistical analysis and average content of analyzed heavy metals in $\mathrm{mg}^{-\mathrm{dm}^{-3}}: \mathrm{Zn}, \mathrm{Pb}, \mathrm{Cu}, \mathrm{Al}$ and $\mathrm{Cd}$ in $\mu \mathrm{g} \cdot \mathrm{dm}^{-3}$ - in rainwater samples (WD), runoff from copper roof (M), roof cover with thermally bonded tar paper $(\mathrm{P})$ and ceramic tiles (C) are shown in Table 3.

\section{Zinc}

The rainwater samples collected during rainfall episodes are characterized by the lowest concentrations of heavy metals. The highest content of zinc was observed in the runoff from the roof covered with tar paper $-15.520 \mathrm{mg} \cdot \mathrm{dm}^{-3}$. The concentration of $\mathrm{Zn}$ in runoff from ceramic tile roof also exceeded the II class of cleanliness, ac- cording to REM. The research carried out in Texas by Chang et al. [2004], comparing the quality of runoff from roofs with different coverage, shows the highest concentrations of zinc for a wooden shingle roof - median $9.717 \mathrm{mg} \cdot \mathrm{dm}^{-3}$ and galvanized iron - median $8.219 \mathrm{mg} \cdot \mathrm{dm}^{-3}$. However, the maximum content of zinc in the runoff from the roof covered with galvanized iron was 212.330 $\mathrm{mg} \cdot \mathrm{dm}^{-3}$ [Chang et al., 2004]. In the study conducted in Gdańsk in 2003-2004, the highest concentration of zinc was observed in roof runoff covered with asbestos cement sheets -4.900 $\mathrm{mg} \cdot \mathrm{dm}^{-3}$ [Polkowska and Namieśnik, 2008].

\section{Aluminum}

The aluminum concentrations in the samples from all types of roofing materials were very low -4 to 40 times less than the reference value for II class of cleanliness, according to REM. The highest concentration was noted for the roof covered with thermally bonded tar paper, which may be dependent on considerable material roughness of this kind of material and the smaller roof inclination angle compared to other roofs. It is estimated that the average aluminum content in the atmosphere in urban areas is $10^{-7}-5 \cdot 10^{-6} \mathrm{mg} \cdot \mathrm{dm}^{-3}$. The major sources of aluminum in urban area are traffic, atmospheric dust, products of fuel combustion; thus, deposition (wet and dry) can also be an explanation for the presence of aluminum in samples of runoff from roofs. Other studies indicate higher aluminum content for the roofs covered with wooden shingle $-0.224 \mathrm{mg} \cdot \mathrm{dm}^{-3}$ and galvanized iron $-0.194 \mathrm{mg} \cdot \mathrm{dm}^{-3}$ comparing to the values obtained for Gdańsk. In the case of

Table 2. Criteria for assessing the quality of inland surface water and others according to Annexes No. 6 and No. 9 to the Environmental Minister Regulation [Journal of Laws,2016 item 1187]

\begin{tabular}{|c|c|c|c|c|c|c|}
\hline \multicolumn{7}{|c|}{ According to Annex No. 6} \\
\hline \multirow[t]{2}{*}{ Name of the indicator } & Unit & \multicolumn{5}{|c|}{ Limit value } \\
\hline & & I & II & III & IV & $\mathrm{V}$ \\
\hline Zinc & $\mathrm{mg} \cdot \mathrm{dm}^{-3}$ & \multicolumn{2}{|c|}{$\leq 1$} & \multicolumn{3}{|c|}{ not specified } \\
\hline Copper & $\mathrm{mg} \cdot \mathrm{dm}^{-3}$ & \multicolumn{2}{|c|}{$\leq 0.05$} & \multicolumn{3}{|c|}{ not specified } \\
\hline Aluminum & $\mathrm{mg} \cdot \mathrm{dm}^{-3}$ & \multicolumn{2}{|c|}{$\leq 0.4$} & \multicolumn{3}{|c|}{ not specified } \\
\hline \multicolumn{7}{|c|}{ According to Annex No. 9} \\
\hline \multicolumn{2}{|l|}{ Cadmium } & 1 & II & III & IV & $\mathrm{V}$ \\
\hline Annual average & $\mu \mathrm{g} \cdot \mathrm{dm}^{-3 *}$ & 0.08 & 0.08 & 0.09 & 0.15 & 0.25 \\
\hline Maximum allowable concentration & $\mu \mathrm{g} \cdot \mathrm{dm}^{-3} *$ & 0.45 & 0.45 & 0.60 & 0.90 & 1.5 \\
\hline \multicolumn{7}{|c|}{ Lead } \\
\hline Annual average & $\mathrm{mg} \cdot \mathrm{dm}^{-3}$ & \multicolumn{5}{|c|}{0.3} \\
\hline Maximum allowable concentration & $\mathrm{mg} \cdot \mathrm{dm}^{-3}$ & \multicolumn{5}{|c|}{1.0} \\
\hline
\end{tabular}

* Note: the mean and maximum admissible concentrations for cadmium are given in $\mu \mathrm{g} / \mathrm{dm}^{3}$ 
Table 3. Basis statistics of trace metals in samples: WD - rainwater, $\mathrm{M}$ - runoff from copper roof, $\mathrm{P}$ - runoff from thermally bonded tar paper and $\mathrm{C}$ - runoff from ceramic tile samples

\begin{tabular}{|c|c|c|c|c|c|c|c|}
\hline \multirow{2}{*}{ Element } & \multirow{2}{*}{ Symbol } & \multirow{2}{*}{ Units } & \multirow{2}{*}{ Value } & \multicolumn{4}{|c|}{ Types of rainwater sample } \\
\hline & & & & WD & M & $P$ & C \\
\hline \multirow{4}{*}{ Copper } & \multirow{4}{*}{$\mathrm{Cu}$} & \multirow{4}{*}{$\mathrm{mg} \cdot \mathrm{dm}^{-3}$} & Mean & 0.002 & 10.231 & 0.099 & 0.020 \\
\hline & & & Min & 0.001 & 7.469 & 0.088 & 0.014 \\
\hline & & & Max & 0.003 & 11.766 & 0.109 & 0.024 \\
\hline & & & SD & \pm 0.000 & \pm 1.957 & \pm 0.009 & \pm 0.004 \\
\hline \multirow{4}{*}{ Zinc } & \multirow{4}{*}{$\mathrm{Zn}$} & \multirow{4}{*}{$\mathrm{mg} \cdot \mathrm{dm}^{-3}$} & Mean & 0.007 & 0.067 & 15.520 & 1.470 \\
\hline & & & Min & 0.005 & 0.046 & 13.503 & 1.147 \\
\hline & & & Max & 0.008 & 0.083 & 16.762 & 1.646 \\
\hline & & & SD & \pm 0.001 & \pm 0.016 & \pm 1.439 & \pm 0.229 \\
\hline \multirow{4}{*}{ Lead } & \multirow{4}{*}{$\mathrm{Pb}$} & \multirow{4}{*}{$\mathrm{mg} \cdot \mathrm{dm}^{-3}$} & Mean & 0.001 & 0.003 & 0.006 & 0.001 \\
\hline & & & Min & 0.001 & 0.002 & 0.005 & 0.001 \\
\hline & & & Max & 0.001 & 0.003 & 0.007 & 0.001 \\
\hline & & & SD & \pm 0.000 & \pm 0.000 & \pm 0.001 & \pm 0.000 \\
\hline \multirow{4}{*}{ Aluminum } & \multirow{4}{*}{$\mathrm{Al}$} & \multirow{4}{*}{$\mathrm{mg} \cdot \mathrm{dm}^{-3}$} & Mean & 0.008 & 0.008 & 0.152 & 0.009 \\
\hline & & & Min & 0.005 & 0.006 & 0.133 & 0.006 \\
\hline & & & Max & 0.001 & 0.008 & 0.184 & 0.011 \\
\hline & & & SD & \pm 0.002 & \pm 0.001 & \pm 0.023 & \pm 0.002 \\
\hline \multirow{4}{*}{ Cadmium } & \multirow{4}{*}{$\mathrm{Cd}$} & \multirow{4}{*}{$\mu \mathrm{g} \cdot \mathrm{dm}^{-3}$} & Mean & 0.025 & 0.355 & 0.600 & 0.063 \\
\hline & & & Min & 0.018 & 0.231 & 0.444 & 0.050 \\
\hline & & & Max & 0.029 & 0.451 & 0.690 & 0.070 \\
\hline & & & SD & \pm 0.005 & \pm 0.092 & \pm 0.111 & \pm 0.009 \\
\hline
\end{tabular}

aluminum sheet, the average aluminum content in the runoff was only $0.169 \mathrm{mg} \cdot \mathrm{dm}^{-3}$ [Chang et al., 2004]. This is the evidence of low leaching ability of the main building material - aluminum - during the atmospheric precipitation.

\section{Copper}

The copper concentration in the runoff from copper roof showed definitely a different result than corresponding aluminum content in the runoff from roofs covered with aluminum sheet. The observed value $-10.231 \mathrm{mg} \cdot \mathrm{dm}^{-3}$, exceeds the limit value specified for II class of cleanliness according to REM by 200 times. The research conducted by Sakson et al. [2014] in Łódź in 20092013 confirms the high copper content in the runoff from copper roofs and other metal roofs. The maximum copper concentration observed was $6.993 \mathrm{mg} \cdot \mathrm{dm}^{-3}$. The tests carried out in New Zealand [Charters F.J. et al., 2016] for 24 episodes of precipitation, among others for copper roofs and sacred architecture, indicates a significant copper leaching with rainwater runoff in the first phase of rain as well as in the final stages. The average value was $1.298 \mathrm{mg} \cdot \mathrm{dm}^{-3}$, and the maximum was $7.861 \mathrm{mg} \cdot \mathrm{dm}^{-3}$. The research carried out by
Charters et al. [2016] clearly proves that the external copper transport (atmospheric deposition) in the case of copper roofs can be practically eliminated. In addition, it should be noted that the analyzed copper roof in Gdańsk Oliwa is covered with a coating of patina. Numerous studies indicate that the runoff from old copper roofs (covered with patina) and new ones, without the final product of atmospheric corrosion of copper and its alloys, differ in the concentration of copper leached out of the roof. The research conducted by Pennington and Webster-Brown [2010] shows that the concentration of $\mathrm{Cu}$ in the outlet from the roof covered with patina is about $35 \%$ lower than in the case of the new copper roof. In the runoff from new roofs in New Zealand, concentrations of $1.000-6.830 \mathrm{mg} \cdot \mathrm{dm}^{-3}$ were observed, while for copper roofs covered with patina they were lower and amounted to $0.773-4.000 \mathrm{mg} \cdot \mathrm{dm}^{-3}$ [Pennington and Webster-Brown, 2010].

The copper concentration in the runoff from the roof covered with thermally bonded tar paper also exceeded the limit for II class of cleanliness; however, in this case, it is possible to assume that copper originated from the atmospheric contamination with this element, probably as a result of anthropogenic activity. 


\section{Lead}

The lead concentrations measured in the runoff from the roofs in Gdańsk Oliwa district were significantly lower than the recommendations issued by the Environmental Minister (REM). The highest lead content $-0.006 \mathrm{mg} \cdot \mathrm{dm}^{-3}$ - was obtained in the runoff from the roof covered with tar paper. In the study of Namieśnik and Polkowska [2008], a similar level of lead concentration was found in the runoff from this type of roofing - average leaching level $-0.001 \mathrm{mg} \cdot \mathrm{dm}^{-3}$. The highest lead content obtained for the runoff from the roof covered with tar paper (in comparison to other materials) may be related to the roughness and small inclination roof angle, which widely facilitates deposition and accumulation of impurities.

\section{Cadmium}

The highest concentration of cadmium in the runoff from the analyzed roofs was recorded for the roof covered with thermally bonded tar paper, copper roof and ceramic tiles, respectively. All of the analyzed samples met the conditions for the I class of cleanliness specified in REM. The obtained values are much lower than those observed by Namieśnik and Polkowska [2008], amounting to $3.700 \mu \mathrm{g} \cdot \mathrm{dm}^{-3}$ for the runoff from ceramic roof tiles.

\section{Potential impact of HM washed from the roofs on surface water receivers}

High concentration of copper found in the runoff from the roof covered with copper can be a cause for concern about the further spread of copper in the environment. In the Old Oliwa district, where the research was conducted, there are more roofs with coatings or at least elements of copper. The runoff from the roofs is discharged into the rainwater drainage system. The rainwater drainage systems flow out to the Oliwa Stream. In studies carried out by Wojciechowska et al. [2017] and Nawrot et al. [2017], increased concentrations of copper were measured in the bottom sediments collected from the retention tank No.5, located in Oliwa district. Due to the decreased flow velocity in the retention tanks, sedimentation of suspensions solids occurs within them. Suspended solids transport other pollutants, such as heavy metals adsorbed on their surfaces [Gajewska et al., 2013, Obarska-Pempkowiak et al., 2015]. The concentration of copper at the measurement point located near the inflow to the retention tank was
$88.79 \mathrm{mg} \cdot \mathrm{kg}^{-1} \mathrm{~d} . \mathrm{m}$.; this corresponds to the contamination of sediments at moderate to significant level, according to the German classification LAWA [1998]. It can be stated that in the case of the analyzed Stara Oliwa district, the copper roofs contribute quite significant $\mathrm{Cu}$ loads to the storm water runoff and constitute a source of copper in the environment. While the quality of water in the Oliwa Stream in respect to trace the metal content corresponds to the I class, according to REM [Wojciechowska et al., 2017], in the case of the sediments deposited for longer periods of time (dredging tanks at intervals once every 4-7 years), the trace metals are deposited and can act as potential sources of contamination in the urban catchment area.

\section{CONCLUSIONS}

1. The runoff from roofs can be a source of trace metals in the environment due to leaching during precipitation, contributing to non-point pollution in the urban catchment area.

2. The runoffs from different types of roofing materials contain various concentrations of heavy metals. In the research conducted in the Gdansk Oliwa district, it was found out that the highest concentration of copper occurred in the runoff from the roof covered with copper the average concentration amounted to 10.231 $\mathrm{mg} \cdot \mathrm{dm}^{-3}$. The highest concentration of lead $-0.006 \mathrm{mg} \cdot \mathrm{dm}^{-3}$, cadmium $-0.600 \mu \mathrm{g} \cdot \mathrm{dm}^{-3}$, aluminum $-0.152 \mathrm{mg} \cdot \mathrm{dm}^{-3}$ and zinc -15.520 $\mathrm{mg} \cdot \mathrm{dm}^{-3}$ were measured in the runoff samples from the rafting finished with thermally bonded tar paper. The ceramic tiles roof was characterized by the lowest metals concentrations in the runoff.

3. Copper roofs, which are a frequent kind of cover for sacral architecture or other buildings, are durable, aesthetic and give buildings prestigious appearance, can be a threat to the state of the environment due to the significant copper leaching.

\section{Acknowledgements}

The work was completed under a GRAM grant, awarded in a competitive procedure by the Dean of the Faculty of Civil and Environmental Engineering, Gdansk University of Technology. The grants are funded from science funds as specified in Journal of Laws no. 96, heading 615, as amended. 


\section{REFERENCES}

1. Chang M., McBroom M.W., Beasley R.S., 2004. Roofing as a source of nonpoint water pollution. Journal of Environmental Management, 73, 307-315.

2. Charters F.J., Cochrane T.A., O'Sullivan A.D., 2016. Untreated runoff quality from roof and road surfaces in a low intensity rainfall climate. Science of the Total Environment, 550, 265-272.

3. Gajewska M., Stosik M., Wojciechowska E., Obarska-Pempkowiak H., 2013. The impact of wastewater treatment technologies on the particle size spectrum in the outflow (in Polish). Rocznik Ochrona Środowiska, 15(11), 1191-1206.

4. http://pomiary.gdmel.pl/

5. Kotowski A., Kaźmierczak B., Dancewicz A., 2010. Modeling of precipitation for sewage sizing (in Polish) PAN Komitet Inżynierii Lądowej i Wodnej Instytut Podstawowych Problemów Techniki, Warszawa.

6. Kaye J., Groffman P., Grimm N., Baker L., Pouyat R., 2006. A distinct urban biogeochemistry? Trends in Ecology and Evolution 21, 192-199.

7. Kim R-H., Lee S., Kim Y-M., Lee J-H., Kim S-K., Kim S-G., 2005. Pollutants in rainwater runoff inKorea: their impacts on rainwater utilization. Environmental Technology, 26, 411-420.

8. Länderarbeitsgemeinschaft Wasser (LAWA), 1998. Beurteilung der Wasserbeschaffenheit von Fließgewässern in der Bundesrepublik Deutschland - Chemische Gewässergüteklassifikation.

9. Nawrot N., Matej-Łukowicz K., Wojciechowska E., 2018. Change of heavy metals concentrations in sediments deposited in retention tanks on Oliwa Stream in Gdansk after the flood incident, Polish Journal of Environmental Studies, in press.

10. Obarska-Pempkowiak H., Gajewska M., Wojciechowska E., Pempkowiak J. 2015. Treatment Wetlands for Environmental Pollution Control. Rowiński P. (ed.) GeoPlanet: Earth and Planetary
Sciences. Springer International Publishing, pp. 169.

11. Ociepa E., Kisiel A., Lach J., 2010. Contamination of rainwater flowing into sewage systems (in Polish). Proceeding of ECOpole, Vol. 4, No. 2.

12. Pennington S.L., Webster-Brown J.G., 2010. Stormwater runoff quality from copper roofing, Auckland, New Zealand. New Zealand Journal of Marine and Freshwater Research, 42(1), 99-108.

13. Polkowska Ż., Namieśnik J., 2008. Road and roof runoff waters as a source of pollution in a big urban agglomeration (Gdansk, Poland). Ecological Chemistry and Engineering, Vol. 15, No. 3.

14. PN-EN 12056-3:2002. Systemy kanalizacji grawitacyjnej wewnątrz budynków - Część 3: Przewody deszczowe - Projektowanie układu i obliczenia.

15. Sakson G., Zawilski M., Badowska E., Brzezińska A., 2014. Zanieczyszczenia ścieków opadowych jako podstawa wyboru sposobu ich zagospodarowania, Journal of Civil Engineering, Environment and Architecture, t.XXXI, z.61 (3/I/14), 253-264.

16. Sneddon, R., Trembly, L., 2011. The New Zealand King Salmon Company Limited:Assessment of Environmental Effects - Copper and Zinc. Prepared for The NewZealand King Salmon Company Ltd. Cawthron Report No. 1984, pp. 53.

17. Tsakovski S., Tobiszewski M., Simeonov V., Polkowska Ż., Namieśnik J., 2010. Chemical composition of water from roofs in Gdansk, Poland, Environmental Pollution 158, 84-91.

18. Wallinder L.O., Leygraf C., Karlen C., Heijerick D., Janssed C.R., 2001. Atmospheric corrosion of zinc based materials: runoff rates, chemical speciation and ecotoxicity effects, Corrosion Science 43, 809-816.

19. Wojciechowska E., Rackiewicz A., Nawrot N., Matej- Łukowicz K., Obarska-Pempkowiak H., 2017. Studies on the distribution of heavy metals in bottom sediments of reservoirs in the urban basin (in Polish). Rocznik Ochrona Środowiska, 19, 572-589. 